However, during a recent visit to Utrecht (Holland), I was allowed to examine the extensive collection of slides belonging to the Hubrecht Laboratory, and observed a modification of the chorionic ectoderm of Lacerta agilis similar to the teloderm of Sphenodon. In Lacerta, as in Sphenodon, these cells are very large, roughly columnar, with well-marked boundaries and domed free edges. The characteristic colour of teloderm when stained with borax carmine is less evident, probably because the sections are rather thinner than those of Sphenodon in the Dendy collection (King's College, London), and also probably because of a different staining technique, though the sections appear to be stained with borax carmine. Teloderm in Sphenodon always overlies immediately another ectodermal layer, in which the cells are ill-defined, more or less cubical and often distinguished only with the greatest difficulty. In Lacerta agilis these underlying ectodermal cells of the chorion are much more evident.

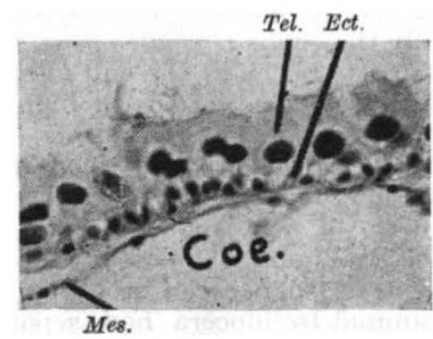

Section through the chorion of Lacerta agilis. $\times 350$. Tel. teloderm; ect., underlying ectoderm; mes, somatic mesoderm coe, extra-embryonal colom between chorion and amnion

I wish to express my gratitude to Prof. Raven and Dr. P. D. Nieuwkoop of the Hubrecht Laboratory, Utrecht, and to Prof. D. Mackinnon of the Zoology Department, King's College, London. The photomicrograph was prepared by Mr. Green, of the Zoology Department, King's College, London.

Biology Department,

St. Mary's Hospital

Medical School,

London, W.2.

May 3.

${ }^{1}$ Fisk, A., and Tribe, M., Proc. Zool. Soc. Lond., 119, Pt. 1 (1949).

2 Dendy, A., Quart. J. Microscop. Sci., 42, 1 (1899).

${ }^{3}$ Schauinsland, H., Anat. Anz., 15 (1899).

4 Mehnert, E., Morph. Arb., 4 (1895).

${ }^{5}$ Kerbert, C., Arch. mikro. Anat., 13 (1876).

\section{Natural Epizootics of Polystoma integerrimum in Tadpoles}

ThE life-history of the monogenetic Trematode, Polystoma integerrimum, has been studied experimentally by Zeller, ${ }^{1,2}$ and by Gallien ${ }^{3}$. Both made some field observations, but no full investigations of natural epizootics appear to have been made. A quantitative study of about a thousand tadpoles, with about four thousand parasites, in seven epizootics has now been made, in which the course of the epizootics has been followed through the various stages. The experimental observations have been broadly confirmed, but the events in Nature do show certain differences, and some new facts have been found.

Wide differences exist between the epizootics, but a general plan can be seen in all. The eggs laid by the adult fluke hatch at two main periods, one at the end of April or beginning of May, and the second about a month later. Some of the larvæ which hatch from these eggs (the primary larvæ) become neotenic larvæ, which lay eggs hatching in July (secondary larvæ).

In some ponds, all tadpoles metamorphose in June. The neotenic cycle in these ponds is therefore abortive, because by the time the secondary larvæ hatch there are no tadpoles. Infestation is secured in these ponds by the presence of primary larvæ, particularly those of the second brood. In other ponds, many tadpoles can be found in July or August, and they become infested with the secondary larvæ, even if they have been almost free from the parasites up to that date.

There are large losses of parasites from the gill chamber throughout the season. It seems important for the parasites that some should enter the tadpoles as near to the date of metamorphosis as possible, not only because the gill chamber is not a very safe location, but also because there is a high mortality among tadpoles. Late infestation short-circuits tadpole mortality. It is suggested that late infestation rather than mere multiplication may be the chief function of the neotenic cycle.

The parasite appears to be without deleterious effect upon its host. Tadpoles are just as large when parasitized as when free from infestation.

At the early stages of infestation there is a tendency for the larger tadpoles to have more parasites than the smaller ones.

Tadpoles are not, in Nature, normally infested until well after the stage when they still have external gills. Only one tadpole was found to be infested at this stage. This contrasts with the work of Gallien, who found in laboratory experiments that tadpoles infested after this stage did not afterwards contain neotenics. It was necessary to take younger tadpoles in order that some of the larvæ should develop in this way.

The parasites are not distributed among the tad. poles at random. There is a tendency for a tadpole to be either more heavily infested than statistical considerations would suggest, or else less heavily infested, the intermediate numbers being relatively rare.

A full account of the observations will be published elsewhere.

"Rosenlaui", Parkgate Crescent, Hadley Wood, Barnet, Herts. May 5.

1 Zeller, E., Z. wiss. Zool., 22,1 (1872).

a Zeller, E., Z. wiss. Zool., 27, 238 (1876)

sallien, L., Trav. Stat. Zool. Wimeraux, 12 (1935).

\section{Enzyme Activity and Nitrogen Content of $E$. coli}

Few investigations on protein-poor micro-organisms have been reported so far. It is the purpose of the present paper to summarize results of investigations concerning the enzymatic equipment of bacteria in increasing nitrogen deficiency. Escherichia coli was cultured in synthetic media containing saccharose, dipotassium hydrogen phosphate, sodium chloride, magnesium sulphate and ammonium sulphate. The concentration of the latter varies from 1,600 to 6 mgm. per litre nutrient solution. The protein content of the cells varies with the nitrogen content of the culture media : when the concentration of ammonium sulphate is reduced below 200-400 mgm. per litre, a 